\title{
THE NEW ROLE OF THE COURTS IN DEVELOPING PUBLIC WELFARE LAW
}

\section{ST. JOHN BARRETT*}

Three years ago it could be said that the federal courts played virtually no role in shaping the rules which determine whether an individual is eligible for public assistance under federally financed programs. The intervening period has seen a dramatic change. Whereas until January 1967 the federal courts had finally adjudicated but one action on welfare grants under 42 U.S.C. $\S 1983$, the provision most readily invoked for such action, ${ }^{1}$ the Commerce Clearing House today publishes the Poverty Law Reporter to inform practicing attorneys of pending litigation and court decisions in this rapidly developing field.

This article will attempt to examine both the reasons for and the significance of this burst of welfare litigation activity. Before doing so, however, it is necessary to outline briefly the statutory structure of public welfare in the United States and the mechanisms by which welfare rules were developed before the courts were projected onto the scene.

\section{The Statutory Structure}

Prior to the enactment of the Social Security Act $^{2}$ in 1935 the administration of public assistance to needy persons was a state and

* Deputy General Counsel, Department of Health, Education, and Welfare. A.B. 1943, Pomona College; LL.B. 1948, Boalt Hall School of Law, University of California. The views expressed in this article are those of the author and do not necessarily reflect the views or policies of the Department of Health, Education, and Welfare or of its Office of General Counsel. The author wishes to express his appreciation to Mr. Joel Cohen, Assistant General Counsel, and Mrs. Frances White, an attorney in the Division of Social and Rehabilitation Service, without whose advice and assistance this article could not have been written.

1. Note, Federal Judicial Review of State Welfare Practices, 67 Colum. L. Rev. 84, 115 (1967).

2. Act of Aug. 14, 1935, ch. 531, 49 Stat. 620, as amended, 42 U.S.C. $\S \S 301-1394$ (1964), as amended, (Supp. 1V, 1969). 
local function. Local welfare officials. often on an essentially ad hoc basis, dispensed public largess to those who were determined to be both destitute and deserving. and neither community attitude nor the law contemplated any recourse for a rejected applicant. The Great Depression and the resulting enactment of the Social Security Act marked a change, in some degree, in both attitudes and law. In denying a means of livelihood to large numbers of persons more skilled, articulate, and politically aware than the traditional "poor." the Depression caused a "democratization of poverty" which resulted in an increased concern for the objectivity and fairness of the rules. ${ }^{3}$

Presently, welfare programs in the United States generally fall into two groups. The older form of assistance, paid for and administered by state and local government, is known as "general assistance." Federal financial support provided under the Social Security Act has been termed "categorical assistance," the Act providing for federal cost sharing in state programs to assist categories of the needy as defined in the Act: The aged in Title $1,^{5}$ needy families with children in Title IV, Part A,' the blind in Title $X,{ }^{7}$ and the permanently and totally disabled in Title XIV. ${ }^{8}$ A state may participate in one or more of these programs, but to do so, it must submit a plan to the federal agency meeting the requirements of the federal statute.' If the state submits a plan meeting all the statutory requirements and including no provisions expressly prohibited by the statute, the federal administrator then "shall" approve the plan..$^{10}$

3. Cf. Friedman, Public Housing and the Poor: An Overview, 54 CALIF. L. REv. 642, 64546 (1966).

4. See Kelly v. Wyman, 294 F. Supp. 893, $895-96$ (S.D.N.Y. 1968), affd sub nom. Goldberg v. Kelly, 38 U.S.L.W. 4223 (U.S. Mar. 23, 1970).

S. Social Security Act, 42 U.S.C. $\S \S 301-306$ (1964), as anended, (Supp. IV. 1969).

6. ld. $\$ \S 601-609$.

7. Id. $\$ \$ 1201-1206$.

8. Id. $\S \S 1351-1355$.

9. Some of the morre significant requirements common to all of these programs are that the plan be state-wide in operation, that it be administered by a single responsible state ageney, that it provide that all individuals wishing to make application for assistance under the plan have an opportunity to do so, that such assistance be furnished with reasonable promptness to all eligible individuals, and that an applicant have an opportunity for a "fair hearing" before the state agency if his "claim for assistance" under the plan is denied or is not acted upon with reasonable promptness. E.g., 42 U.S.C. $\$ \$ 602$ (a). 1202(a), 1352(a) (Supp. IV, 1969).

10. 42 U.S.C. $\$ \$ 302(b), 602$ (b), 1202(b), 1352(b) (Supp. IV, 1969). 
Once a plan is approved, the state is entitled to federal financial contributions for both assistance payments and administrative costs. Considerable latitude is given the state in defining who is "eligible" for assistance, and the state may restrict eligibility to a class that is smaller than the broadest group for which federal matching funds would be available." By the same token the state plan may define eligibility in terms broader than the federal definition without voiding the entire plan; the state must merely assume the full cost of providing assistance to those individuals who fall outside the federal definition. ${ }^{12}$

The Act also permits the federal administrator considerable latitude in deciding whether state plans meet the statutory requirements. The policies developed in the administrator's passing upon state plans have been customarily embodied in the Handbook of Public Assistance Administration. ${ }^{13}$ Until recently, the Handbook provisions were not formally promulgated as regulations or published in the Federal Register, although they were given the effect of regulations. ${ }^{14}$

Basic eligibility requirements and some of the more basic procedures are fixed in each state by state law. The various states have customarily set forth and expanded their "plan" provisions in a welfare "manual,"'s the state's official rule book for operating the welfare programs, which also derives its authority from state law. In many states the application and payment process is actually administered by city or county officials who use the "manual" as their guide.

If a state enacts a welfare law, adopts a manual provision, or implements in practice a standard or procedure which is inconsistent with the Social Security Act or with the federal Handbook, the Secretary of the Department of Health, Education, and Welfare is

II. See. e.g., Social Security Act, 42 U.S.C. $\$ 302(\mathrm{a})(10)(B)(1964)$, which gives the states power to determine eligibility for assistance. See generally U.S. DeP'T OF Htalth, EDuc. \& iVflifare. Handibook of Public Assistance administration, pt. IV, $\$ 5500$ [hereinafter cited as HANDBOOK].

12. For a discussion of totally state-funded programs, that is, general assistance, see note 4 supra and accompanying text.

13. HANDBOOK.

14. 45 C.F.R. $\$ 201.3($ d) (1969).

15. See, e.g., N.C. Board of Public IVelfare. North Carolina Public assistance Manial of Policies and Procedures for administration of Oln age Assistanct. Aid to Deph:Ndest Children and Aid to the Per uanently and Totally Disablid (1952). 
empowered to determine, after notice and opportunity for a hearing, that the state is not "in conformity" with federal requirements and is no longer entitled to receive federal contributions for the particular welfare program in which the violation occurs. ${ }^{16}$ If dissatisfied with the Secretary's determination, the state may seek judicial review in the Court of Appeals. ${ }^{17}$ The end result of a determination that the state is out of conformity is the complete termination of federal funds for the program, or, in the discretion of the Secretary, the offending portion of the program. Although no lesser remedy is provided, a recent court decision relating to another federal program suggests that the United States may have a claim in federal court for injunctive relief to compel the state to abide by federal requirements. ${ }^{18}$

\section{Methods of Developing THE Rules}

It is one thing to understand the formal mechanics of rule making and legislation. It is something else to understand how rules are actually shaped and who influences their shaping. As indicated by the above, there are essentially four levels of legal rules in the welfare area: The federal statute, the federal policy embodied in the Handbook, the state statutes, and state policy embodied in the state welfare plans and manuals. This section will first consider the development of rules at the grass-roots level-the state welfare manual - and then work up to the federal statutory level.

State plans and amendments are prepared by state welfare officials and submitted to federal officials for review and determination of whether they conform with federal law and policy. Whatever the pressures acting upon the state welfare officials-and important among these will be political pressures for reduced spending - the essential dialogue in arriving at suitable language for the manual provisions will be between a professional welfare worker at the state level and a professional welfare administrator at the federal level. If these two officials are satisfied with their mutual product, the deal is closed.

The process of formulating state legislation differs little from the processes involved in formulating state welfare manual provisions.

\footnotetext{
16. See, e.g., 42 U.S.C. $\S 304$ (1964), as amended, (Supp. IV, 1969).

17. Social Security Act $\S 1116,42$ U.S.C. $\S 1316$ (Supp. IV, 1969).

18. United States v. Frazer, 297 F. Supp. 319 (M.D. Ala. 1968).
} 
Except for intermittent concerns about saving tax dollars and improving the morals of welfare recipients, a state legislator ordinarily has little concern with the technicalities of welfare legislation. It is drafted by the same professionals from the state department of public welfare who draft the manual provisions, and it is ordinarily drafted with one principal object in mind-to meet the federal requirements for federal funding. Thus, to ensure compliance when state legislation is being considered, just as when state regulations are being drafted, the federal professionals will be consulted by the state professionals, and often the language of the state statute itself will have been suggested, if not drafted, by a federal official.

Again, at the federal rule-making level, the process remains in the hands of welfare professionals. Here, however, the concern of federal administrative officials is turned to members of Congress who, as influential members of appropriations or other committees, have become more or less expert in welfare law. Unlike other areas of national legislation such as public health, where there has traditionally been an influential and articulate constituency outside the Government, the dialogue in developing legislation and rules in the welfare area has been, until recently, essentially between the federal and state administrators and members of Congress. And, the influence of congressional committee members has extended beyond the formulation of federal administrative rules to encompass the actual application of such rules in practice. A federal official called before an appropriations subcommittee having the power of life or death over much of his program will find it difficult to refuse commitments on how particular statutory provisions or administrative rules will be applied. Once such a commitment is made, there exist few counteracting pressures to deter the federal welfare of ficial from carrying it out. ${ }^{19}$

It is thus hardly surprising that the established modes of developing welfare rules should have discouraged innovation, free and open public discussion, and responsiveness to the needs and feelings of the welfare recipients. However, new factors and

19. This rule-making dialogue between congressional committees, or committee members, and the federal administrator has often been conducted in executive session of a committee or by some other means not involving public notice or disclosure. For a consideration of similar exercises of legislative "supervision" of administrative action. see W. Gellior. * C. Byse, Cases on Administrative Law 166-95, 181 n.43 (1960). 
conditions have recently altered the rule-making system and have initiated profound changes in the rules themselves.

\section{Ven Elements in the Equation}

To a lawyer, the most obvious new element in the development of welfare "rules" is the role of the courts. In its past two Terms the Supreme Court has held durational residence requirements in welfare to be unconstitutional:20 has ruled state "man-in-the-house" provisions in AFDC ${ }^{21}$ to be contrary to the Social Security Act; ${ }^{22}$ has determined that a welfare recipient need not exhaust his administrative remedies in order to challenge the validity of welfare rules in federal court: $:^{23}$ and has affirmed a state's right to recover past payments of welfare.2- In the present Term the Court will determine issues of due process in welfare administrative hearings, ${ }^{25}$ has set for argument a case concerning the validity of the new HEW regulation implementing the decision in King $v$. Smith ${ }^{26}$ and has already heard argument on the validity of state-imposed "family maximums" for benefits under AFDC. ${ }^{27}$

Yet. the activity of the courts, though important, is only part of the story. The role of the poor people in enlisting court scrutiny of the welfare program and the effect of the court decisions in stimulating action by welfare administrators and Congress constitute the rest of the story.

20. Shapiro v. Thompson. 394 U.S. 618 (1969).

21. Aid to Families with Dependent Children. See 42 U.S.C. $\$ \$ 601-09$ (1964), as amended. $\$ \$ 601-10$ (Supp. 1V, 1969).

22. King v. Smith, 392 U.S. 309 (1968), noted in 18 BuFfal.o L. Rliv. 623 (1969), 18 DEPALL L. REv. 897 (1969), and 52 MARQ. L. REv. 422 (1969).

23. Damico v. California. 389 U.S. 416 (1967).

24. Snell v. Wyman. 393 U.S. 323 (1969). affig mem. 281 F. Supp. 853 (S.D.N.Y. 1968).

25. Wheeler v. Montgomery, 296 F. Supp. 138 (N.D. Cal. 1968), rev'd, 38 U.S.L.W. 4230 (U.S. Mar. 23, 1970); Kelly v. Wyman. affd sub nom. Goldberg v. Kelly, 38 U.S.L.W. 4223 (U.S. Mar. 23, 1970). [Ed. note: see note* following note 104, p. 128 infra.]

26. Lewis v. Stark, Civil No. 50238 (N.D. Cal., Dec. 23, 1968), prob. juris. noted sub nom. Lewis v. Montgomery, 396 U.S. 900 (1969) (No. 560 Misc.; renumbered No. 829,1969 Term), hearings scheduled sub nom. Lewis v. Martin, 38 U.S.L.W. 3302 (Feb. '17, 1970) (No. 829).

27. Dandridge v. Williams. 297 F. Supp. 450 (D. Md. 1968), noled in 4 GA. L. Rev. 203 (1969). [Ed. note: While this article was at press, the Supreme Court reversed the district court's decision. 38 U.S.L.W. 4277 (U.S. April 6. 1970).] For a review of similar cases decided and pending in the lower federal courts, see CCH POVERTY L. REP. 


\section{The Poor and the Courts}

The economically underprivileged who recently have asserted increasing pressure upon the welfare system are drawn largely from the racial minorities of American society. Experienced by the civil rights movement of the last decade, they brought to the welfare battle a drveloped leadership schooled in both direct action-by way of protest demonstration and civil disobedience-and court action. Pressures from these poor have found a ready point of focus in the courts because legal counsel has been available to initiate litigation. Although for some years free legal services were available to the indigent in urban areas to defend against criminal prosecutions and, in some cases, civil actions, only very recently has counsel been available to indigents to initiate and sustain lawsuits to determine and enforce their legal rights. For the past two or three years such counsel, largely through the arm of neighborhood legal services supported by the Office of Economic Opportunity, has been available for this purpose in virtually every metropolitan area. In addition, the practice of "poor people's law" has attracted some of the most energetic and able of our recent law school graduates.

Nevertheless, it is conceivable that the courts might not have undertaken an affirmative role, even with available counsel to get welfare issues before them. Indeed, it seems fair to assume that similar issues brought before the courts 50 years ago would have received a withering response. Even as recently as 1967 , the United States District Court for the District of Columbia dismissed a suit instituted by a welfare recipient seeking injunctive relief against "nighttime visits" by welfare workers, stating that there was no "right" to welfare and that the court therefore need not and should not determine the propriety of the complained-of practice..$^{28}$ In an earlier era this dichotomy between "right" and "privilege" would have been sufficient to bar relief to the welfare recipient or applicant in virtually any court in the country-no matter how available and able the legal counsel. ${ }^{2 \theta}$

By 1967, however, many of the judges - at least those sitting on the federal courts - had received considerable experience in handling cases brought against government officials on issues involving the

\footnotetext{
28. Smith v. Board of Comm'rs, 259 F. Supp. 423 (D.D.C. 1966).

29. See Van Alstyne, The Demise of the Right-Privilege Distinction in Constitutional Law, 81 HARV. L. REv. 1439 (1968).
} 
right of individuals to such public "privileges" as professional licenses, government employment, and entering into government contracts. In handling these cases the courts had become somewhat accustomed to applying rules that arose from cases involving the direct imposition of government restraints upon the citizen-the free speech, unlawful police practices, and raeial discrimination cases. Furthermore, because of the considerable volume of cases under the fourteenth amendment relating to racial discrimination, the courts were not only well experienced in dealing with official-defendants reluctant to change methods of administration generally condoned by the community; the courts also had become accustomed to enforcing the rights of underprivileged individuals without the aid of a clear congressional mandate.

The judiciary thus projected into the pieture, all elements were present for a rapid and orderly development of the law. First, four different sets of rulemakers were now involved-the Congress, the federal administrators, the state administrators, and the courts. This permitted a sort of four-sided game of leapfrog. If for any reason the federal administrators were inhibited in the development of new rules-perhaps because of the disapproving views of members of an appropriation committee-the courts could assume the lead in developing new legal requirements. Once the courts had spoken, the federal administrators could then respond by framing a rule embodying the judicially-enunciated principle, perhaps even embellishing it a bit. State administrators would also find themselves somewhat freed by the court decisions and the federal rule making to undertake innovations that otherwise might have been inhibited by local political pressures. Such state-developed innovations would, in turn, give federal officials, federal judges, and the Congress a greater assurance in developing and applying similar rules nationally. Development of the law could thus proceed in an everascending spiral with no single participant in the process having the capacity to block progressive development.

One element, sometimes present in developing areas of the law but not present in the welfare area, might have impeded any orderly development responsive to the poor people's demands. This is the element of a clearly defined, deeply committed, and influential opposing interest group. Opposition to a procedural rule in the administration of the welfare program or to a rule defining eligibility for assistance is relatively diffuse: the only person having a strong 
and direct interest is the welfare applicant or recipient. A welfare worker, while he may disagree with a change in the rule, can hardly feel that it is a bread and butter issue for himself. An ordinary citizen not on welfare is affected only to the extent a change in welfare rules may result in additional spending and increased taxes. Thus, while disagreement with new welfare rules may be broadly based and sometimes reinforced by racial or social prejudice, it is unlikely to be deeply felt or sharply focused. This permits the rulemakers-legislators, administrators, and courts - to go about their business fairly undisturbed.

The importance of this absence of a strong and articulate opposing interest group can best be appreciated by comparing the development of rules in the welfare area with the development of rules in a somewhat related area-that of racial discrimination in federally supported programs as forbidden by Title VI of the Civil Rights Act of $1964 .^{30}$ Much like the welfare situation, essentially all the elements necessary for a speedy and orderly development and application of the law to eliminate racial discrimination were present. The subject of desegregating public schools, however, was a gut issue for a majority of the citizens in the southern states and hence for their Congressmen. For this reason, although the same four types of rulemakers were involved, if one of the actors advanced even slightly beyond the others he was subjected to very strong adverse pressure through the Congress, the press, and other avenues of public and political influence.

The pressures to which the courts were subjected after the Supreme Court's 1954 decision in Brown v. Board of Education ${ }^{31}$ are well known. For many years implementation of the decision was in large measure frustrated on the charge that the courts had exceeded their authority and were usurping "legislative" functions. The enactment of the Civil Rights Act of $1964^{32}$ muted many of these cries, the initiative being given federal administrators to eliminate discrimination in educational programs receiving federal financial assistance. However, when the Commissioner of Education issued his implementing "guidelines" 33 he soon found himself, along

30. 42 U.S.C. $\S \S 2000 \mathrm{~d}$ to $2000 \mathrm{~d}-\dot{4}$ (1964).

31. 347 U.S. 483 (1954). See generally J. Peltason. Fifty-Eight Lonely Men l-29 (1961).

32. 42 U.S.C. § 2000 (1964).

33. 45 C.F.R. $\$ 180(1969)$. 
with the Secretary of Health, Education, and Welfare, summoned before congressional committees to explain why they were going beyond court decisions and congressional mandates. ${ }^{34}$ The administrators, no less than the courts, were subject to vituperation and pressures which impeded the orderly development and enforcement of the law. ${ }^{35}$

In the welfare area the courts not only are relatively free from adverse pressures in developing a rule of law; they have an unusually wide assortment of tools with which to accomplish it. The fact that there are four rulemakers-congressional, federal administrative, state administrative, and court-means not only that there will be interaction among the four, but also that the courts in deciding cases can do so on constitutional, federal statutory, federal regulatory, state statutory, or state regulatory grounds. Obviously, this makes for a great deal of flexibility. A federal court, while issuing a stern warning about a constitutional problem, can at the same time avoid deciding the constitutional issue and construe the Social Security Act in such a way as to reach a result which general principles of equity seem to require. Or the court may give broad effect to a federal regulation and thereby invalidate a conflicting state statute or administrative practice. And, as the role of the courts has increased, initiative in the rule-making process has shifted from the welfare administrators and the legislators to the welfare recipients - the plaintiffs in the lawsuits. The administrator is no longer left to decide just when and how he will meet a particular issue. Rather, he will be forced to meet the difficult problems at the time, and more or less on the terms, that the plaintiffs choose.

With this general discussion of the elements of the process as background, an examination of two concrete examples should prove helpful. The first example involves the development of the rule that a welfare recipient given notice of termination of his assistance is

34. See Hearings on Proposed Cutoff of Welfare Funds to the State of Alabama Before the Senate Conim. on Finance, 90th Cong., Ist Sess. 74 (1967) (testimony of Hon. John W. Gardner, Secretary, Dep't of Health, Education, and Welfare); Hearings on Guidelines for School Desegregation Before the Special Subcomm. on Civil Rights of the House Conim. on the Judiciary, 89th Cong., 2d Sess., ser. 23, pt. 1, at 4 (1966) (testimony of Hon. Harold Howe, 11, U.S. Comm'r of Education); Hearings on H.R. 826. Policies and Guidelines for School Desegregation Before the House Comm. on Rules, 89th Cong., 2d Sess. 27 (1966) (testimony of Hon. Harold Howe, 11, U.S. Comm'r of Education).

35. See Wedemeyer \& Moore, The American Welfare System, 54 CALIF. L. REv. 326 (1966); 67 Colum. L. REv., supra note 1. 
entitled to continued payments pending a decision after "fair hearing" on the question of his eligibility. The second example involves the development of the substantive rule that a state may not deny a family assistance under AFDC on the grounds that a man not the father of the children is in the home as a "substitute father."

Termination of Assistance Pending Hearing. The Social Security Act requires that each state plan provide an applicant an opportunity for "fair hearing" before the state agency if his "claim for assistance under the plan is denied or is not acted upon with reasonable promptness." 38 The federal Handbook applies this hearing requirement not only to the rejection of applications, or delay in acting upon them, but also to the "suspension or discontinuance of assistance in whole or in part." Although the statute does not state whether the hearing should be held before or after the adverse action by the agency, the Handbook indicates that the hearing is to be after the suspension or discontinuance of assistance; and, until recently, none of the states administering federal welfare programs provided a "fair hearing" prior to termination of assistance..$^{38}$ Despite the obvious hardship that such a rule can visit upon a welfare recipient whose benefits are wrongly terminated, the rule was not seriously challenged or reconsidered until early 1967.39

In June 1967, an action was filed in the United States District Court for the Northern District of Mississippi by a Mr. Williams and his wife to compel state and local welfare officials to restore the husband to the welfare rolls under the program for the permanently and totally disabled..$^{10} \mathrm{Mr}$. Williams was a 30-year old Negro living in Leflore County, Mississippi, whose formal education ended after the fifth grade in a rural Mississippi school. He had worked only at

36. See, e.g., Social Security Act $\S 2(a)(4), 42$ U.S.C. $\S 302(a)(4)$ (1964).

37. HANDBOOK, pt. IV. $\S 6300$ (c)(1) (1968).

38. See Note, The Constitutional Minimum for the Ternination of Welfare Benefits: The Need for and Requirentents of a Prior Hearing, 68 MicH. L. Rev. 112, 113 \& n.5 (1969).

39. Comment, Withdrawal of Public Welfare: The Right to a Prior Hearing, 76 YALE L.J. 1234 (1967). The author urged that the requirements of due process precluded termination of benefits to a welfare recipient without affording him an opportunity for prior hearing, arguing that the principle applied by the courts in licensing and regulatory cases-that an administrative action based on a factual determination shall not be effective until a hearing is afforded-should apply with equal or even greater force to a welfare recipient whose very livelihood is threatened by administrative action terminating his benefits. Id.

40. Williams v. Gandy, Civil No. GC-6728 (N.D. Miss., filed June 9, 1967), noted in 10 Welfare L. Bull. 7 (Oct. 1967). 
[Vol. 1970:1

unskilled manual labor. In 1965, while working in a cotton mill at Greenwood, Mississippi, he suffered an accident resulting in the loss of his right hand. Thereafter, he applied for and received aid to the permanently and totally disabled, and his wife and nine children applied for and received aid for families with dependent children. In early $1966 \mathrm{Mr}$. Williams was further diagnosed as having sickle cell anemia, pulmonary tuberculosis, and chorelithiasis and was advised by his doctor that he could not return to any work. In November of 1966, Mr. Williams obtained a prosthesis for his right arm consisting of a double-prong hook. He alleged in his complaint that with the prosthesis he could grasp certain small objects but was unable to lift heavy objects. Be that as it may, a report came to the county welfare officials that he had been seen at his home splitting kindling with a hatchet.

In April 1967, Mr. Williams was told by his social worker that he was "not disabled enough" for aid and that the grant for his children would probably also be discontinued in another year. About two weeks later he received a notice in the mail from the welfare department stating that his case was being closed. The sole information in the notice regarding the reason for this action read: "[o]ur reasons for coming to this decision are as follows: The medical information shows you are not disabled enough to meet our rules for Aid to the Permanently and Totally Disabled."'1

After getting help from a Mississippi-based attorney who had been working on civil rights matters in the state, Mr. Williams filed a request for a hearing. He also requested and was allowed to examine the "hearing file" created by the welfare officials for use in his future administrative hearing. The only information in the file regarding the reasons for terminating his assistance was the statement that "the impairment [of plaintiff] is not total as defined in agency policy."'2

Not having received any response to his request for a hearing, Mr. Williams filed the lawsuit two months after his assistance had been terminated. He alleged, among other things, that the termination of his assistance without prior hearing denied him due process of law. He requested the convening of a three-judge court and moved for an order temporarily restraining the suspension of his benefits pending a hearing.

41. Id.

42. Id. 
The filing of this lawsuit produced fast results. The defendants, rather than going to trial, agreed to restore Mr. Williams's aid payments. They further agreed to continue welfare payments, pending fair hearing, to all recipients that the state had determined to have lost their eligibility because no longer disabled. This commitment was formalized in an amendment to the Mississippi welfare manual in May 1968, continuing assistance in all terminations pending fair hearing..$^{13}$

Mississippi's response to the Williams suit put it far ahead of any other state and, indeed, ahead of federal policy, in continuing assistance pending hearing. But the obvious question for the Mississippi state administrators was: Would the federal government provide matching funds for the assistance payments made pending the administrative hearings? The provision of the federal Handbook previously had not allowed such matching.

On July 11, 1967, the Department of Health, Education, and Welfare sponsored a meeting on fair hearings in public assistance, attended by federal, state, and local welfare officials and representatives of civil rights and welfare rights groups. At the meeting, one of the points most strongly urged upon the federal officials was the need for continuance of financial assistance pending the fair hearing decision. A month later the Department issued a summary of the meeting which, in commenting on this particular point, stated that under existing policy for federal matching a local agency was required to terminate assistance within 30 days after a local welfare agency had decided, before a hearing, that a recipient had become ineligible. Six days later, however, Under Secretary Wilbur Cohen was to announce at a meeting of welfare officials his "Eight Points," be available for states if they continued assistance pending a hearing decision. This new rule was incorporated in the Handbook the following February..$^{15}$

On this issue, at least, the welfare rights victory in Mississippi had been complete. Nationally, however, the victory was only partial. While Mississippi had changed its policies to provide

43. 3 Miss. Dep't of Pub. Welfare, Manual $\S$ F, at $6100-03$ (1968).

44. The "Eight Points" of Mr. Cohen consisted of a statement of newly adopted welfare polices, then unpublished, which were circulated to state and local welfare officials attending the meeting. Copies are on file with HEW as an unpublished document.

45. HANDBooK, pt. IV, § 6500(b) (Feb. 2, 1968). 
continued welfare payments pending decision of an administrative appeal, the federal agency had determined only that it would "match" such payments, not require that states make them. Because of Mississippi's change in policy the court never decided the constitutional issue in the Williams case. Before the end of the year, however, the same issue was raised in Wheeler $v$. Montgomery, ${ }^{46}$ a suit filed by welfare recipients in a federal court in San Francisco.

While the Wheeler case was pending, California undertook to change its fair hearing procedures to provide more adequate notice to recipients whose aid was about to be terminated, full information to them regarding the evidence on which termination was predicated, and an informal conference with the recipient at which he would be given a full explanation and an opportunity to counter with information or argument on his own behalf. The new procedures provided for termination after the conference but prior to the full "fair hearing" that was required by the statute. 17 This new proposal to continue welfare payments until after the informal conference gave California an interest similar to that which Mississippi had in being assured that federal matching would be available for such payments. The California officials accordingly urged the Department of Health, Education, and Welfare to issue a Handbook amendment as soon as possible that would permit nationally the kind of matching that had been agreed to with Mississippi. As already noted, such an amendment to the Handbook was made on February 8, 1968. This settled the issue of "matching." The issue of "conformity," that is, whether the federal rule would require that each plan provide for assistance pending decision on fair hearing, remained unsettled.

Before the Wheeler case came to trial before the three-judge district court in San Francisco, the plaintiff, Mae Wheeler, had been restored to old-age assistance, and the California State Department of Welfare, having been assured that federal matching funds would be available, had adopted the new procedures calling for an informal conference before termination. Although the court retained jurisdiction of the case as a class action, it decided on the merits that

46. 296 F. Supp. 138 (N.D. Cal. 1968), rev'd, 38 U.S.L.W. 4230 (U.S. Mar. 23, 1970).

47. Cal. State Dep't of Social Welfare. Public Services Manual, Reg. 44-325.434 (April 1, 1968). 
the new California procedures met the requirements of due process and dismissed the complaint. ${ }^{48}$

About the time that the three-judge court was dismissing the San Francisco suit, the construction of Resurrection City and the Poor People's March in Washington, D.C. were getting into high gear. On April 30, 1968, Reverend Abernathy served his first set of demands on the federal government departments, including a demand that the Department of Health, Education, and Welfare adopt a policy requiring that aid payments be continued until fair hearing appeals were decided.$^{49}$ In responding to this demand a month later, Secretary Cohen said only that "as of July 1, 1968 we will require that any agency may not reduce or discontinue a payment without first notifying the recipient in advance and giving him time to question the facts or the contemplated action and discuss them."50 This was essentially the California rule.

In a second set of demands on behalf of the Poor People's campaign, Reverend Abernathy repeated that HEW "should act now ... to make full assistance payments during appeals from decisions to reduce or terminate payments." 51 ln responding this time, Secretary Cohen finally committed the Department to "require the States to continue assistance to families where discontinuance or reduction of assistance is being appealed, with appropriate safeguards to assure proper and efficient administration of the provision." 52

While HEW was in the process of meeting the poor's demands on this point, yet another lawsuit raising the issue was filed in a federal court. In Kelly v. Wyman, ${ }^{53}$ a number of plaintiffs in New York City sued to enjoin enforcement of the New York rules which required termination of welfare benefits immediately upon a determination of ineligibility, in both the federally-funded categorical assistance programs and the state supported general

48. Wheeler v. Montgomery, 296 F. Supp. 138 (N.D. Cal. 1968), rev'd, 38 U.S.L.W. 4230 (U.S. Mar. 23, 1970).

49. Unpublished document on file with HEW.

50. Letter from Secretary Cohen to Reverend Ralph Abernathy, May 25, 1968, on file with HEW.

51. Statement of Reverend Ralph D. Abernathy on Goals of Poor People's Campaign, Press Release by Reverend Abernathy (June 11, 1968), on file with HEW.

52. Letter from Secretary Cohen to Reverend Ralph Abernathy, June 18, 1968, on file with HEW.

53. 294 F. Supp. 893 (S.D.N.Y. 1968), affd sub nom. Goldberg v. Kelly, 38 U.S.L.W. 4223 (U.S. Mar. 23, 1970). 
assistance program. At the time the complaints were filed the New York rules required no prior notice of suspension of payments and no hearing prior to such action. With respect to the general assistance program, a rule had been adopted only two weeks before the action was filed requiring that a hearing be afforded after termination of benefits. ${ }^{54}$

While the Kelly case was pending before the district court in New York, the Department of Health, Education, and Welfare was developing and considering a new regulation which would require the continuation of payments pending a fair hearing decision on termination or reduction of assistance in all cases in which the issue turned on a disputed fact or the applicability of an eligibility rûle to a particular recipient. On October 30,1968, the Administrator of the Social and Rehabilitation Service proposed such a rule to Secretary Cohen, who approved it on November 26, 1968 same date on which the federal court in New York rendered its decision in Kelly that due process required, prior to ternination, an opportunity to be confronted with the evidence upon which termination was based, an opportunity to confront and crossexamine witnesses, and the right to present evidence and argument on one's own behalf. ${ }^{56}$ In publicly announcing the new regulation, which, in some respects, cut more broadly than the decision in Kelly would have required, the Department emphasized that "[t]his policy is in line with a decision handed down this week, as a matter of constitutional requirement, by a three-judge federal district court in New York." 57

The new rule, scheduled to go into effect on July 1, 1970, has evoked considerable opposition from state administrators, and its final form will be determined largely by the manner in which the courts resolve some of the basic statutory and constitutional issues in the pending cases..$^{58}$

\footnotetext{
54. 18 N.Y. Codes, RuLE, \& Reguiations 84.2 .23 (1968). It is perhaps revealing of the general attitude toward,welfare recipients and of the relative lack of development of the law in this area that as late as 1968 the state of New York had no hearing provision whatever in its general aid program.

55. 34 Fed. Reg. 1144 (1969).

56. Kelly v. Wyman, 294 F. Supp. 893 (S.D.N.Y. 1968), affd sub nom. Goldberg v. Kelly, 38 U.S.L.W. 4223 (U.S. Mar. 23, 1970).

57. HEW Press Release (Nov. 29, 1968).

58. It is interesting to note that although some of these issues-including what constitutes an adequate hearing and whether state-funded legal counsel must be provided-are currently under review by the Supreme Court, the lower federal courts are continuing to grant relief in
} 
"Man-in-the-House." There is a long tradition in the administration of public welfare of devoting available resources to those of the needy who are "worthy." With respect to needy children, this question of worthiness has taken the form of aiding those in a suitable home environment. Thus, 50 years ago aid to children would ordinarily go to the children of a widow of good repute. Children of a woman divorced, and certainly of a woman unmarried, could expect little help from a public welfare agency. ${ }^{59}$ Although the withholding of welfare to children because of an unsuitable home of course did nothing to improve the environment, the moral judgment of the community was expressed by refusing tax monies to support them. Unfortunately, this left in need those who were perhaps in greatest need and had its most severe impact on members of racial minority groups.

Perhaps the strongest community, and hence public welfare, disapproval was visited upon mothers of children born out of wedlock who lived with a man other than the children's father. The welfare rules excluding such mothers and children from public aid have variously been denominated as "man-in-the-house," "substitute father," "unfit home," and "man-assuming-rolc-ofspouse" rules. ${ }^{60}$ While all of these rules had a common element relating to the sexual misconduct of the mother, varying emphasis was placed on the character of the home environment, the presence of an adult male as a source of income, and the immorality of the mother as reasons for denying aid.

When the Social Security Act was enacted in 1935 it was quite clear from the debates and committee reports that Congress intended the states to have considerable latitude in fixing eligibility requirements for public welfare and did not intend to preclude the states from looking to the "moral character" of the applicants." The statute itself, however, was silent on this point.

cases similar to Wheeler and Kelly without awaiting the Supreme Court's decision. See, e.g., Machado v. Hackney, 299 F. Supp. 644 (W.D. Tex., 1969); Caldwell v. Laupheimer, Civil No. 69-397 (E.D. Pa., Nov. 3, 1969); Sims v. Juras, Civil No. 69-238 (D. Ore., Aug. 21, 1969); Thomas v. Graham, Civil No. 69-141 (D. Ariz., July 11, 1969); Robertson v. Born, Civil No. 51364 (N.D. Cal., June 12, 1969); Miller v. Zoeller, Civil No. 69-C-2 (W.D. Wis., Jan. 20, 1969).

59. See generally W. BeLl, AID to Dependent ChiLdRen 3-19 (1965).

60. See O'Neil, Unconstitutional Conditions: Welfare Benefits with Strings Attached, 54 Calif. L. Rev. 443 (1966).

61. H.R. Rep. No. 615, 74th Cong., 1st Sess 18, 24 (1935); S. ReP. No. 628, 74th Cong., Ist Sess. 29, 36 (1935). 
In the early years of administering the Act the federal agency encouraged the states to consider the fitness of the home in determining eligibility for aid to dependent children. In time, however, the posture of the federal agency became ambivalent, with some members of the agency urging that it was inconsistent to deny aid to a child because the home in which he was living was "unfit" while doing nothing to improve the home or remove the child from it. That the children should not be punished for the sins of their mothers was suggested with increasing frequency. ${ }^{62}$ Finally, in 1945, the federal agency issued a letter to all state agencies stating:

\begin{abstract}
the "suitable home" provision ... may be in part an expression of the community's concern for the protection of the welfare of children in that sector of the population in which families suffer more than average hazards. This provision, if it is used as an eligiblity requirement, will not, however, protect children. It simply precludes them from receiving aid to dependent children. To expect that such an eligibility requirement will protect children indicates a confusion between what public assistance can do to help parents protect their children and what action can be taken by agencies that have the authority to protect children from their parents, including even the removal of the child from his home."
\end{abstract}

This letter, however, was purely precatory, and most states with suitable home policies continued to enforce them.

The failure of the federal agency to take any affirmative action despite its officially expressed views continued until 1960. In that year the legislature of Louisiana passed a law under which the fact of an illegitimate birth created the presumption that the mother's home was "unsuitable" for any of her children. ${ }^{\text {ot }}$ Within a few months Louisiana eliminated over 23,000 children from its welfare rolls, 95 percent of whom were Negro..$^{65}$

The plight of the Louisiana children and the focus of national publicity compelled the Department of Health, Education, and Welfare to cite Louisiana for a hearing to determine whether its new practices were "in conformity" with the federal law. After a hearing the Commissioner of Social Security reluctantly concluded that there was nothing in the federal law which prevented Louisiana from imposing this eligibility requirement. The next day, and just three

62. See generally W. BELL. supra note 59, at 20-56.

63. Id. at 150 .

64. Act No. $251 \S 1,1$ La. Acts 1960 at 527, as amended, LA. Rev. StAt, ANN. § 46:?33.D(10) (Supp. 1969).

65. W. BELL. supra note 59, at 137-51. 
days before he was to leave office with the outgoing adininistration, Secretary Arthur S. Flemming announced that he was adopting a new policy to become effective on July 1, 1961, outlawing all "suitable home" requirements. ${ }^{66}$ Although Congress itself probably never could have been induced to enact this "Flemming Rule," it quickly accorded it a backhanded endorsement by prohibiting the Secretary from withholding funds from any state for violation of the rule before the state had an opportunity to make any necessary amendments to its own statutes in order to comply. ${ }^{67}$

Still, Mr. Flemming's midnight coup left many questions unresolved. For example, even though a state might be inhibited from ruling children ineligible because their homes were "unsuitable," might the state still exclude children if their mother were cohabiting with a man who could be considered a "substitute parent" for the child? After all, the eligibility of most children for aid depended upon the "absence" of the father from the home; if the mother had a de facto husband, did not her children necessarily have a de facto father?

The Department took no clear position on the "substitute father" issue except insofar as such position might be implied from its continued acceptance of state plans which included "substitute parent" provisions..$^{68}$ This was an issue, however, that was bound to come to a head. Unlike procedural issues relating to fair hearing, questions of illegitimacy, men living with welfare families while refusing to assume parental responsibilities, and the dramatic increase in the AFDC rolls, possessed considerable sex appeal for the public and for substantial numbers of Congressmen. The issue could not and did not lie unresolved for long.

In the summer of 1962 , a subcommittee of the Senate Appropriations Committee, chaired by Senator Byrd of West Virginia, in considering the fiscal 1963 appropriations for the District of Columbia, undertook to investigate the administration of public welfare in the District. The efforts of District officials to eliminate from the welfare rolls families with which a man other than the spouse or the father was living figured prominently in the hearing. The Deputy Commissioner of the Social Security

66. State Letter No. 452, Bureau of Public Assistance, Social Security Administration, Department of Health, Education and Welfare (Jan. 17, 1961).

67. Social Security Act $\S 404$ (b), 42 U.S.C. $\S 604$ (b) (1964).

68. See generally W. BELL, supra note 59 , at 148. 
Administration was called before the committee and asked to explain the Flemming Rule and the application of federal policies to the practices being pursued by the District's welfare administrators. In testifying, Mr. Meyers, the Deputy Commissioner, drew a distinction between a state rule disqualifying a child because some man other than his father has informally assumed the role of parent, and a state law requiring, contrary to the Flemming Rule, that the home be "suitable" or that the mother's conduct be proper. Pressed by Senator Byrd, Mr. Meyers testified:

\section{Senator Byrd.}

Well, after your having heard the explanations of today concerning the meaning of the rule as it has been applied in the District of Columbia, you have not found, on the basis of these explanations, any instances in which the District has violated the Federal statute. Is that correct?

Mr. Meyers.

Let's put it this way. The man-in-the-home policy, as particularly just explained by Mr. Brewer, although not one that the Federal Government necessarily espouses or recommends, is one which is-

Senator Byrd.

Nor-let me say on the part of the Congress-necessarily condemns.

Mr. Meyers.

Well, that is right. Some of those cases we would pay for, if the District wanted to go ahead and pay them. But it certainly is not required. And to adopt a policy, as stated that way, would be perfectly consistent with Federal requirements. And if in application the criteria used in determining whether or not there actually was this parent substitute relationship, where adequate, then again there could be no question under the Federal requirements.

Senator Byrd.

Very good.99

This colloquy fixed the policy of the Department: a "suitable home" rule would be regarded as inconsistent with federal requirements, while a "substitute parent" rule would be permissible.

In 1964, Alabama submitted to the Department some new state plan material under AFDC, including a "substitute father" provision..$^{70}$ The Alabama rule, however, provided that a child would be considered as having a substitute father if "he lives in the home with the child's . . . mother for the purpose of cohabitation," or if "he visits frequently for the purpose of cohabiting with the ... mother," or if "he does not frequent the home but cohabits with the

69. Hearings on H.R. 12276 Before a Subcomm. of the Senate Comm. on Appropriations, 87th Cong., 2d Sess. 2240 (1962).

70. See generally King v. Smith, 392 U.S. 309, 313-16 (1968). 
child's natural or adoptive mother elsewhere."71 Despite Alabama's denomination of this as a "substitute father" rule, the last of the three described situations could hardly be considered as having any bearing on parental relationship, and the first two looked only to "cohabitation." Accordingly, the federal agency declined to approve the plan material. Nevertheless, the state operated under the plan and HEW took no steps to institute a conformity hearing. The situation between HEW, the states, and the Congress remained in equilibrium until 1967.

In October of 1966, Mrs. Sylvester Smith, who lived with her four children in Dallas County, Alabama, was removed from the AFDC welfare rolls bcause Dallas County welfare officials had determined that a Mr. Williams, who was not the father of any of Mrs. Smith's children, regularly came to her home on weekends and had sexual relations with her. Except for these weekend visits, Mr. Williams lived with and supported a wife and nine children of his own. He contributed nothing and was able to contribute nothing to the support of the Smith children. Mrs. Smith filed suit in federal court against the Dallas County welfare officials, attacking the validity of Alabama's "substitute father" rule. Counsel for Mrs. Smith urged, and the district court held, that Alabama's denial of aid to children whose mothers engaged in extramarital sexual relations, whilè affording aid to other children, was a denial of equal protection of the laws. ${ }^{72}$ The state appealed.

The case was pending before the Supreme Court at the time of the Poor People's March on Washington. The initial demands of the Poor People, to which reference has been made, called upon the Department of Health, Education, and Welfare to "eliminate the infamous 'man-in-the-house' rule now-without waiting for a court decision. A petition for this action was submitted to the Secretary of Health, Education, and Welfare more than two years ago. It has never been acted on." 73 Secretary Cohen responded: "We do not favor or support State 'man-in-the-house' rules. We urge the States to repeal these requirements. We expect the Supreme Court of the United States to rule on this matter shortly and will take action in light of the Court decision."

71. Alabama Manual for administration of Public assistance, pt. I, ch. II, $\S$ VI.

72. Smith v. King, 277 F. Supp. 31 (M.D. Ala. 1967), aff d. 392 U.S. 309 (1968).

73. Unpublished document on file with HEW.

74. Letter from Secretary Cohen to Reverend Ralph Abernathy, June 14, 1968, on file with HEW. 
[Vol. 1970:1

On June 17,1968 , the Supreme Court rendered its decision in King $v$. Smith ${ }^{75}$ Although the case had been decided below and argued before the Supreme Court on constitutional grounds, the Court avoided a constitutionally-based decision and voided the Alabama rule on federal statutory grounds-an approach which could hardly have been anticipated by one familiar with the structure and history of the Social Security Act. The Court held, in effect, that if a state chooses to provide AFDC assistance for needy children because they have been deprived of parental support by the absence of a "parent," it must provide such assistance for all such children, and that the state in determining whether a child has an absent "parent" is bound by the federal definition of the word. Before this decision it had been assumed by federal administrators that the state could, by adopting a more restrictive definition of "absent parent" under its own law, limit the size and cost of its program without forfeiting federal assistance.

The day after the Supreme Court's decision, Secretary Cohen issued a further response to the Poor People, stating:

In accordance with the Supreme Court ruling on Monday, the inclusion in the family, or the presence in the home, of a "substitute parent" or "manin-the-house" will not be an acceptable basis for a State for finding children ineligible for AFDC. We are issuing to the States appropriate regulations to carry out the Supreme Court decision. ${ }^{78}$

For present purposes it is probably as well to end the story there. Suffice it to say that the Secretary did issue new regulations to implement the Supreme Court decision; ${ }^{77}$ the regulations sought to anticipate certain further questions not expressly dealt with by the Supreme Court; the State of California challenged the regulations as going beyond the federal statute and the Supreme Court decision, and the challenge was victorious in a three-judge federal district court. ${ }^{78}$ The matter is now pending before the Supreme Court. ${ }^{70}$

\footnotetext{
75. 392 U.S. 309 (1968), noted in 18 Buffalo L. Rev. 623 (1969), 18 DePAUL L. Rev. 897 (1969) and 52 MARQ. L. REv. 422 (1969).

76. Letter from Secretary Cohen to Reverend Ralph Abernathy, June 18, 1968, on file with HEW.

77. 45 C.F.R. 203.1 (1968).

78. Lewis v. Stark, Civil No. 50238 (N.D. Cal., Dec. 23, 1968), prob. juris. noted sub nom. Lewis v. Montgomery, 396 U.S. 900 (1969) (No. 560 Misc.; renumbered No. 829, 1969 Term), hearings scheduled sub nom. Lewis v. Martin, 38 U.S.L.W. 3302 (Feb. 17, 1970) (No. 829).

79. Id. See note 26 supra and accompanying text.
} 


\section{Conclusion}

We have discussed what is essentially a federal legislative process-the development of rules, both substantive and procedural, for the administration of welfare. Yet the Congress has played a passive role. Its influence has been essentially negative, inhibiting federal administrators from making changes contrary to the traditional mode of welfare administration.

It is the participation of the courts that has brought the rulemaking process to life. As in other areas of national need in which the legislative process has become paralyzed-such as legislative reapportionment, civil rights and procedural protection for criminal defendants-participation by the courts has been necessary to break the impasse and permit the other institutions of government to respond. Thus, we have another example of apparent reversal in the intended roles of our governmental institutions. Instead of the legislative and executive branches providing the initiative for the creative development of new rules, with the courts imposing a restraining hand when necessary, it has been the courts that have supplied the initiative and, in some measure, the creativity. 
